\title{
Effectiveness of immunization with multi- component bacterial immunomodulator in foals at 35th day of life
}

Anna Migdał ( $\square$ anna.migdal@urk.edu.pl )

University of Agriculture in Krakow

Łukasz Migdał

University of Agriculture in Krakow

Okólski Adam

University Centre of Veterinary Medicine UJ-UR, University of Agriculture in Krakow

Anna Migdał

Polish Academy of Sciences

\section{Research Article}

Keywords: TLR4, IL-6, IL-10, IgM, IgG2, immunization

Posted Date: February 3rd, 2022

DOI: https://doi.org/10.21203/rs.3.rs-1321007/v1

License: (c) (i) This work is licensed under a Creative Commons Attribution 4.0 International License.

Read Full License 


\section{Abstract}

The aim of the study was to investigate the mechanisms leading to immunization through the use of a multicomponent bacterial immunomodulator and to find out the relationship between the TLR 4 receptor with selected parameters of innate immunity and to acquire immunity.

The study was conducted on 18 Polish Pony Horses foals divided into two study groups: control $(n=9)$ and experimental $(n=9)$. Foals from the experimental group received intramuscular duplicate injection of $5 \mathrm{ml}$ of multi-component bacterial immunomodular at 35 and 40 days of age. RNA isolated from venous blood was used to evaluate the expression of TLR4 genes using RT-PCR. Concentration of II-6, IL-10, IgM and IgG2 was determined by the ELISA method in blood plasma.

Immunostimulation had a significant impact on the level of genes expression for TLR4 expression and IL6 concentration. No effect of stimulation on $\operatorname{lgM}$ and $\lg \mathrm{G} 2$ concentrations was found.

The expression of TLR4 genes as well as the levels of interleukins could be modulated by stimulation with a pharmacological agent multi-component bacterial immunomodulator. The experiment demonstrated a strong positive correlation between TLR4 gene expression and IL-6 concentration and between TLR4 gene expression and IgM concentration.

\section{Introduction}

A foal is born capable of an immune response, although at the time of birth it is almost devoid of immunoglobulins. Immediately after birth, only insignificant amounts of $\lg \mathrm{M}$ and $\lg \mathrm{G} 1 \mathrm{can}$ be detected in the blood of newborns [1]. Immediately after birth, foals have $30 \%$ of the number of B cells found in adult animals. The efficiency of $\mathrm{T}$ lymphocytes and neutrophils as well as the activity of the complement system are also lower [2]. In the first days of life, along with increasing exposure to a variety of pathogens, foals respond with a massive expansion of antigen-specific lymphocytes. This response is the result of a progressively increasing number of circulating lymphocytes and the similarly growing mass of peripheral lymphoid organs [3]. Endogenous antibody production at 5-8 weeks of age is minimally sufficient to protect the foal (>40-50 mg/dl). Meanwhile, the concentration of colostral IgG decreases with the half-life thereof, which is $28-32$ days in healthy foals. In foals deprived of colostrum and fed with replacement preparations, the level of endogenous immunoglobulins increases significantly at 2 weeks of age, and at 5 weeks it is comparable or higher than the level of immunoglobulins in the blood plasma of foals fed with mare's milk. In cow colostrum-fed foals, the production of endogenous antibodies is not affected [4]. Neonatal and adult equine B lymphocytes show differences in the profiles of the immunoglobulin $\mathrm{G}$ subclasses and immunoglobulin A production. B lymphocytesin newly born foals mainly produce $\lg G 1$ and $\lg G 3$, while endogenous $\lg G 2$ and $\lg G 4$ are absent. Adults, on the other hand, produce more $\operatorname{lgG} 2$ and $\operatorname{lgG} 4$ [5]. The concentration of $\operatorname{lgG}_{4 / 7}(\mathrm{IgGb})$ in foal blood plasma is variable, and its production appears to be delayed in response to toxins, viruses, and intracellular bacterial infections $[6,7,8]$. Although the production of $\lg 11(\operatorname{lgGa}), \lg G_{3 / 5}(\operatorname{lgGT})$ and $\lg A$ already in the 
first 8-12 weeks of foal life is similar to that of adult horses, the concentration of $\operatorname{lgG}_{4 / 7}$ in foals up to 1 year of age remains lower than in adult horses [9]. The deficiency of some subclasses of immunoglobulins can lead to the impairment of the body's functional protection. Certain genes responsible for the production of immunoglobulins, in particular with IgG4 and IgG7, may have different expression and regulation in foetuses and young foals compared to adult horses [5]. Despite the fact that foals synthesize immunoglobulins in utero, their concentration does not reach the minimum level necessary to provide protection against pathogens by the age of 2 months. In the first weeks of life, the production of endogenous immunoglobulins and the immune response of foals are inhibited by the still present, passively transmitted maternal antibodies. It is difficult to precisely define the period in which the maternal immunity is active, as it depends on a number of factors. The disappearance of passive maternal immunity in a newborn foal occurs about 2-6 weeks after birth [10]. The emerging and increasing resistance to antibiotic therapies forces the search for newer and more effective preventive methods and new animal treatment strategies. It seems that an alternative is the prophylactic immunostimulation of foals before weaning from the mother. There is a growing interest in this type of preparations, which are increasingly often applied in veterinary practice, with promising results. Among immunostimulants, there are compounds of natural and synthetic origin. Natural immunostimulants include compounds of bacterial origin, substances isolated from fungi and from plants. Bacterial stimulants include whole bacterial cells, live bacteria of the genera Bifidobacterium and Lactobacillus, belonging to the group of organisms called probiotics. There are also bacterial extracts and bacterial products with an immune-stimulating effect, including OK 432 (Picibanil), obtained from Streptococcus pyogenes and Streptococcus heamolyticus strains with low virulence, lipopolysaccharides (LPS), which are part of the cell wall of Gram-negative bacteria, as well asmuramyl dipeptide (MDP) and its analogues $[11,12,13,14,15]$. Often, immunotherapy is associated with side effects including injection site reactions, fever, somnolence, and decreased appetite. This is probably related to the induced endogenous release of cytokines. It is desirable to stimulate the immune response without harmful inflammation and tissue damage. The choice of immunomodulators and recommendations for action are still questioned in many cases due to insufficient information on the mechanisms of action in vitro and in vivo, as well as unknown harmful side effects [16]. The innate immune response is a universal defence mechanism against invading pathogens. Toll-like receptors belonging to this line of defence are involved in the recognition of a wide range of microorganisms: bacteria, viruses, and fungi. Nevertheless, few authors dealt with the issue of gene expression for Toll-like receptors in the neonatal period of foals, and there is little information on the shaping of expression of these genes in other farm animals.

So far little is known about the development of the horse immune system during pre- and postnatal periods, which negatively affects devising strategies for maintaining and improving foal health. Based on the knowledge available in the literature, biological properties and the influence of Toll-like receptors on the characteristics of the immune response of farm animals and humans, we hypothesized that the expression of TLR-4 receptor genes and the level of cytokines and immunoglobulins in foals depend on a factor such as bacterial immunostimulation, and especially LPS immunostimulation. 
The aim of the study was to investigate the mechanisms leading to immunization through the use of a multicomponent bacterial immunomodulator and to find out the relationship between the TLR 4 receptor with selected parameters of innate immunity and to acquire immunity after stimulating the immunity with a bacterial preparation in foal up to 60 days of age.

\section{Results}

Influence of stimulation on expression of TLR4 mRNA

Before the injection of the immunomodulator, both groups showed a similar trend in the level of TLR4 mRNA expression. In both groups, a dynamic decrease in the level of expression was observed. The highest level was observed in samples taken before the first suction. In the first 30 days of foal life, a higher level of expression was noted in group $\mathrm{C}$. These differences were highly statistically significant. The level of TLR4 mRNA expression at 30 days of age was similar in both groups (Figure 1). 5 days after the second dose multi-component bacterial immunomodular injection TLR4 mRNA expression increased by $41.33 \%$ (group E), while expression of TLR4 mRNA in foals from group C decreased by $20.22 \% .15$ days after the second injection, the expression of the studied gene in the experimental group decreased, but was still at a higher level than in the control group. On the following days after immunostimulation, $T L R 4$ mRNA expression in foals from group $E$ was higher but no statistical differences were found between groups. Statistical analysis showed statistically significant differences in TLR4 mRNA expression after immunostimulation, in group $E$ between 30th and 40th days of life and at 40th days of life between groups

\section{Influence of stimulation on immunoglobulins concentration}

The changes in the concentration of IgG2 observed during the course of the experiment followed the same pattern in both groups. The highest IgG2 concentration in foals was reported 24 hours after the delivery (group C; $3.20 \pm 1.21 \mathrm{mg} / \mathrm{dl}$ ). In the both control and experimental groups, the lowest concentrations were also observed at day $40(1.68 \pm 0.32 \mathrm{mg} / \mathrm{dl}$ and $1.99 \pm 0.28 \mathrm{mg} / \mathrm{dl}$, respectively). On the remaining days, concentration of IgG2 decreased in both groups (Figure 2). Statistical analysis revealed highly significant differences $(p<0.01)$ in IgG2 concentration between groups $C, E$ at 24 hours, 3 , 510,20 and 30 days of age foals. As well statistically significant differences $(p<0.05)$ between study groups were shown at 40,50 and 60 days of age. Spearman's rank correlation analysis showed a strong positive correlation between the mean daily IgG2 concentration and the mRNA expression of genes for TLR4 $(R=0.58)$.

The dynamics of changes in the concentration of immunoglobulin $M$ in both groups was similar (Figure 2). In the first days of foal life, the IgM concentration increased, reaching the highest values between the $3 r d$ and 5 th day after birth. The highest level was observed on the 5 th day of life in foals from the $C$ group: $26.75 \pm 3.76 \mathrm{mg} / \mathrm{dl}$. In the following days, a decrease in the concentration of these antibodies was observed, with the lowest concentration on the 50th day of life in foals from the E group: $6.04 \pm 1.85$ 
$\mathrm{mg} / \mathrm{dl}$. At 60 days of foal life in all groups, a slight increase in immunoglobulin $\mathrm{M}$ concentration was observed. Statistical analysis showed highly significant differences $(p<0.01)$ between groups $C$ and $E$ betweenthe 30thand 60th day of foal life. There were also significant differences $(p<0.05)$ in the results obtained on day 5 , between group $C$ and group $E$. Spearman's rank correlation analysis showed a strong positive correlation between the mean daily IgM concentration in all groups, and the mRNA expression of the genes for the TLR4 receptor $(R=0.52)$.

\section{Influence of stimulation on cytokins concentration}

The profile of changes in interleukin 6 concentration in all groups was similar (Figure 3). In the first days of foal life, the concentration of IL- 6 has shown a very low level, and during the birth it was at a level that was borderline mark able $(0.4 \pm 0.03 \mathrm{mg} / \mathrm{dl}$ in foal group $\mathrm{C}$. In the following days there was a steady increase in IL- 6 concentration in both groups, whereas in the control group, the highest level was observed on the 60th day of foal life, $1.32 \pm 0.11$, respectively. In the experimental group of the foals, the highest concentration of IL- 6 was recorded on the 40 th day of foal life $1.27 \pm 0.11 \mathrm{mg} / \mathrm{dl}$. The analysis showed a highly statistically significant effect of immunostimulation on the concentration of IL-6.

The conducted experiment did not show any statistically significant changes in the concentration of interleukin-10 between the studied groups. The lowest concentration of IL-10 was observed during delivery, $0.93 \pm 0.12 \mathrm{mg} / \mathrm{dl}$, and the highest, on the 60th day of foal life, $1.13 \pm 0.14 \mathrm{mg} / \mathrm{dl}$, respectively. In the group of foals subjected to immunostimulation (group E), a higher concentration of IL-10 was observed. In this group, the lowest level was observed on the 5th day of life: $0.93 \pm 0.10 \mathrm{mg} / \mathrm{dl}$; and the highest on the 50th day: $2.48 \pm 0.35 \mathrm{mg} / \mathrm{dl}$. Statistical analysis showed highly significant differences between the study groups in IL-10 concentration $(p<0.01)$ on the 50th and 60th day of foal life. Spearman's rank correlation analysis showed a weak positive correlation between the mean daily IL-10 concentration and the mRNA expression of genes for TLR4 $(R=0.14)$.

\section{Discussion}

Despite the availability of newer and more accurate diagnostic, preventive and therapeutic methods, viral and bacterial infections in foals still constitute a major problem in horse breeding. Sepsis remainsa major cause of deaths in newborn foals [19]. In our own research, a highly significant effect of immunostimulation on the level of gene expression for the Toll-like 4 receptor was observed. Vendrig et al. [20] also failed to show the effect of LPS stimulation on the expression level of the studied gene in foals, in contrast to adult horses, in which increased expression was observed under the influence of stimulation. Different results were obtained by Tessier et al. [21], who compared the TLR4 gene expression of cord blood cells and peripheral blood cells in adult horses. The authors reported a strong increase in the expression of the studied gene in response to stimulation with lipopolysaccharides (LPS). Hansen et al. [22], having studied horses aged 5 to 27 years, showed an increase in the level of expression after LPS stimulation, while no reaction after stimulation with PGN (peptidoglycan derived from Staphylococcus aureus extract) was reported. Lin et al. [23], who examined the level of gene expression for TLR4 in pigs, reported a higher value in animals with bacterial Streptococcus suis infection 
and $\mathrm{H} 1 \mathrm{~N} 1$ viral infection, but a significantly higher value of expression was observed in animals with mixed bacterial-viral infection. The studies of the effect of immunostimulation on the expression of the gene for the Toll-like 4 receptor in humans were investigated by Levy et al. [24] and Yerkovich et al. [25]. These studies showed that the level of TLR4 gene expression in the peripheral blood of LPSimmunostimulated neonates was higher compared to non-stimulated neonates and adults. In our own study in the first days of foals life, significant differences between the groups on the level of gene expression for the Toll-like 4 receptor was observed. This requires further investigation and extension of research methods, it has been suggested that dysbiosis of the intestinal microbiota activates TLR4. Horses, like humans, are sensitive to LPS and develop severe endotoxemia, a primary cause of death in cases of equine colic. Since little is known about TLR4 signaling in equine B lymphocytes, the current study analyzed concentrations of cytokines produced by potential TLR4 signaling pathways.

Foal Peripheral Blood Mononuclear Cells (PBMC) actively produce cytokines, including TNF-a, IL-1 beta, IL-2, IL-4, IL-6, IL-8, IL-10, IL-12p35, IL15, and IL-18, already in the first month of life. It has been proven that a small number of PBMCs are enough to increase the expression of IFN- $\gamma$, IL-4 and IL-10, and these proteins are detected after stimulation, already from birth [26]. Breathnach et al. [27] and Wagner et al. [26] observed an increase in IL-10 concentration during the first six weeks of foal life, followed by stabilization at a level similar to that of adult horses. In our own studies in stimulated foals, an increase in the level of IL- 6 was observed along with an increase in the expression of the gene for TLR4, followed by an increase in IL-10. Although the results of analyses of cytokine levels in foals with sepsis are contradictory, this may reflect an immune response to various types of infectious organisms, or a transient immunosuppression. In the authors' own research it was found that the level of IL-6 in the first days of foal life was very low, and it fact, it was borderline measurement possibilities. Similar results were obtained by Burton et al. [28]. However, the increase in IL-6 levels in the following days does not have to be related to endogenous production. In newborn foals, the situation seems to be more complicated. The massive transfer of IL- 6 from colostrum into the bloodstream makes it difficult to assess endogenous production levels. Literature data indicate that mare's colostrum, like the colostrum of other animal species, contains IL-6 $[29,30,31,32]$. As a result, healthy foals that drank sufficient amounts of colostrum after birth have acquired a high concentration of colostral IL-6. This hypothesis was confirmed in calves [33] and piglets [31]. While maternal IL-6 may influence the immune response in the newborn, its exact function in the foal's immune system is still unknown. Our studies showed that the mulicomponents bacterial immunumomodulator activates the TLR4 receptor and the resulting upregulation of cytokine secretion. Our Spearman correlation analysis showed that significant types of differences were positively correlated with TLR4 and IL-10, suggesting activation of the TLR4 / II-10 signaling pathway of immunization. In our study, an increase in the concentration of immunoglobulin $\mathrm{M}$ was observed in the first 3-4 days of foal life, with subsequent decrease until the 50th day of life, when the lowest value was observed. No significant effect of immunostimulation on IgM levels was recorded. The increase in IgM concentration in the first days of life was also reported by Bondo and Jensen [34]. Flaminio et al. [35] observed a higher concentration of IgM in blood samples taken shortly after delivery compared to blood samples taken in the second and third month of foal life. These concentrations, 
however, were lower than those observed in adult horses, which is consistent with the results of own research by Flaminio et al. [35]. In this experiment, no statistical differences were observed between 6week-old Rhodococcusequi-infected versus healthy foals. These results are also confirmed by studies carried out on foals infected with Staphylococcus ureus. IgM concentrations in the serum of healthy and infected foals were at an even level. The influence of age on the level of IgM was observed, as on the 30th day significantly lower concentrations were recorded compared to the results obtained on the first day of foal life [36]. Also studies by Ryan and Giguere [37] showed significantly lower humoral immunity response and lower lymphoproliferation in response to vaccination in newborn foals compared to adult horses, even in the absence of vaccine antigen-specific antibodies. In these studies, the vaccine immune response increased with age, yet 3-month-old foals did not yet respond with the same intensity as adult horses. In newborn foals, no increase in the level of immunoglobulins after immunostimulation was demonstrated, only in 3-month-old foals an increase in $\operatorname{lgM}_{\text {and }} \operatorname{lgG}_{4 / 7}$ was observed, which is confirmed by the results obtained in our own research. Jacks et al. [38] reported different results, because after vaccinating 7-day-old foals with live Rhodococcusequi, they observed a significant increase in IgM concentration. These results indicate that a humoral immune response can be stimulated in newborn foals. However, the nature, the dose of the antigen, and the type of adjuvant, if any, can all have a profound effect on the intensity of the response and the class of immunoglobulin produced. The specific functions for IgG2 are still poorly understood [39]. Few authors describe IgG2 in horses. So far, there are no reports on the level of this immunoglobulin in foals in the first weeks of life. The limited amount of information regarding the IgG2 function in foals is exacerbated by the impossibility of comparing it to other species of mammals, which is due to a different number of immunoglobulin $G$ subclasses. In our study, a very low level of $\mathrm{G} 2$ immunoglobulins was observed, on borderline measurement possibilities, and no effect of stimulation on IgG2 concentration was found. Similar results were obtained by Lewis et al. [40], who analysed the effect of stimulation with protein A obtained from Staphylococcus aureus or with protein $\mathrm{G}$ obtained from Streptococusequi on the concentration of individual immunoglobulin $\mathrm{G}$ subtypes, and found a very weak IgG2 response. The authors suggest that for maximum efficacy, vaccination should target immunoglobulin $G$ responses of the $\lg G 1, \lg G 3, \lg G 4$, and $\lg G 7$ subtype. The paradox of neonatal vaccination is the need for immediate protection in early life and obtaining long-term memory despite the limitations of the infant's immune system and the theory of maternal antibody interference.

In summary on the basis of the results obtained, it was concluded that the expression of genes of TLR4 genes as well as the levels of interleukins could be modulated by stimulation with a pharmacological agent multi-component bacterial immunomodular. The experiment demonstrated a strong positive correlation between TLR4 gene expression and IL- 6 concentration and between TLR4 gene expression and IgM concentration. Detailed knowledge of the molecular mechanisms of immunglobulin synthesis appears necessary for a better understanding of foal immunity maturity and its contributing factors. At the same time, it encourages studies regarding the influence of signalling cascade's proteins on the primary immunological response, which provides an opportunity to develop extremely precise methods of regulating the acquired immunity. There is still little information about the maturity of the horse's immune 
system in the pre- and postnatal period, which negatively affects the planning of foals' health protection strategies.

\section{Methods}

The experiment was conducted upon receiving the permission granted from the Local Ethics Committee in Kraków (No. 37, 30 May 2016).

Animals and feeding

Studies were carried out on 18 foals representing Polish Pony (Konik, Polish Konik) horses. This primitive horse breed is genetically and phenotypically closely related to its wild ancestor, the Tarpan Horse (Euroasian wild horse) [17].

All foals with mares were kept in the same stable in individual boxes (size $2.15 \times 3.50 \mathrm{~m}$ ) on permanent straw bedding at the Experimental Station of the University of Agriculture in Krakow. All animals were clinically healthy throughout the experimental period. Mares of 5 to 17 years of age, and 270 to $340 \mathrm{~kg}$ live body weight, were not vaccinated during pregnancy. Foal birth weight was $27-35 \mathrm{~kg}$, weight loss on the first day of life was $<1.5 \%$. The horses had all been used by university students in the teaching program. No horses were used for equestrian purposes. Inclusion criteria consisted of foals born from healthy mares with no placentitis, normal gestational period, uneventful birth, and having normal physical and neurological examination findings. The foals had to successfully stand and nurse within 2 hours of birth, and remain clinically healthy during the study period.

Mares were fed ad libitum with hay (Lolium 40\%, Trifolium L.20\%) with addition of oat in the amount of $1.5 \mathrm{~kg} / \mathrm{mare}$ per day (according to Institute of Physiology and Animal Nutrition standards, 1997) [18]. Foals were fed only with colostrum and mother's milk ad libitum, without additional supplementation. Water was offered from automatic water drinkers (flow $\sim 10 \mathrm{l} / \mathrm{min}$ ).

Experiment design

320 days of pregnancy, birth alarm (Abfohlsystem, Jan Wolters) was placed in the labia, and mares were moved to box stalls inside a stable, lit with natural light (Supplementary Figure S1). During the experiment, the foals were kept with their mothers in individual boxes, and were leaving the stalls with the mothers for pasture. The following physiological parameters determined the selection of animals for the experiments:

- - blood counts in foals on the first day of life (hematocrit> 40\%, hemoglobin> $13 \mathrm{~g} / \mathrm{dL}$, the level of erythrocytes $9.5 \times 106 / \mu$ l, leukocyte level> $6 \times 103 / \mu \mathrm{l}$ )

- - the quality of the colostrum before the first suckling (immunoglobulin concentration $>30 \mathrm{~g} / \mathrm{dL}$, > $20 \%$ BRIX) 
- - evaluation of the foal's viability in the first 5 minutes. after birth (obtaining min. 8 pts on the Apgar scale)

Foals were randomly assigned into two groups:

- - Experimental Group $(E ; n=9)$ - foals that received the multicomponent bacterial immunomodulator; and

- - Control Group ( $C ; n=9)$ - foals that did not receive the multicomponent bacterial immunomodular or any other pharmacological/additive component that might influence their immune.

.For immunostimutalion used in the present study, multi-component bacterial immunomodulator. It consisted of a mixture of inactivated gram-positive and gram-negative bacteria e.g: Escherichia coli (123 $\mathrm{mg} / \mathrm{ml})$, Staphylococcus aureus $(74 \mathrm{mg} / \mathrm{ml})$, Streptococcus zooepidermicus $(24.6 \mathrm{mg} / \mathrm{ml})$, Streptococcus equi $(24.6 \mathrm{mg} / \mathrm{ml})$, Streptococcus equisimilis $(24.6 \mathrm{mg} / \mathrm{ml})$, Streptococcus agalactiae $(24.6 \mathrm{mg} / \mathrm{ml})$, Streptococcus dysgalactiae $(24.6 \mathrm{mg} / \mathrm{ml})$, Pasteurellamultocida $(123 \mathrm{mg} / \mathrm{ml})$, and Erysipelothrixinsidiosa $(49 \mathrm{mg} / \mathrm{ml})$ as well as pork spleen extract $(10 \mathrm{mg} / \mathrm{ml})$. On day 35 and day 40 after birth, the foals from the experimental group received intramuscular (m.pectoralisdescendens) injection of $5 \mathrm{ml}$ of multicomponent bacterial immunomodulator.

Blood sampling and analysis

Blood samples were collected from foals by jugular venipuncture. Blood samples were obtained from foals until 60 days of age according to the following scheme: before the first suckling, at 1st, 3rd, 5th, 10th, 20th, 30th, 40th, 50th and 60th day of age. Three mililitres of blood were collected into TEMPUS (Applied Biosystems, Tempus ${ }^{\mathrm{TM}}$ Blood RNA Tubes) tubes with RNA stabilizing factor. Samples were stored at $-20^{\circ} \mathrm{C}$ till further processing. Three mililitres of blood were collected into tubes with EDTAk2. The collected samples were centrifuged at5000 rpm for 5 minutes and plasma were stored in $-20^{\circ} \mathrm{C}$ till further analysis.

Isolation of RNA

Isolation of RNA was carried out using TEMPUS SPIN (Ambion) according to the manufacturer's protocol (Supplementary). $1 \mu \mathrm{g}$ RNA was transcribed into cDNA using High Capacity cDNA Reverse Transcription Kit (Applied Biosystems) according to the protocol.

A "No-RT" (non-reverse transcriptase) control was used for selected RNA samples to analyse DNA contamination in RNA samples.

\section{Gene expression analyses}

Gene expression analyses were performed in thelllumina Eco (Illumina) system using TaqMan®MGB probes (Table 1). Every sample was analysed in triplicate in the final volume of $10 \mu$ l (Supplementary Table S1). Amplification was performed according to the following protocol: polymerase activation at 
$95^{\circ} \mathrm{C}(2 \mathrm{~min})$ and 40 cycles: $95^{\circ} \mathrm{C}$ for $15 \mathrm{~s}$ and $60^{\circ} \mathrm{C}$ for $1 \mathrm{~min}$. SDHA and HPRT genes were used as housekeeping genes (Table 1).

Table 1

Probes used for amplification of TLR genes and housekeeping genes.

\begin{tabular}{|cllll|}
\hline Gen & Full name & $\begin{array}{l}\text { Access number } \\
\text { of the gene }\end{array}$ & $\begin{array}{l}\text { Taqmank } \\
\text { assay ID }\end{array}$ & Dene expression \\
\hline TLR4 & Toll-like receptor 4 & NC_009168.2 & Ec03468993_m1 & FAM \\
\hline SDHA & $\begin{array}{l}\text { succinate dehydrogenase } \\
\text { complex subunit A }\end{array}$ & XM_001490889 & Ec03470479_m1 & VIC \\
\hline HPRT & $\begin{array}{l}\text { Hypoxantine phosphoribosyl } \\
\text { transferase }\end{array}$ & AY372182.1 & Ec03470217_m1 & VIC \\
\hline
\end{tabular}

In addition, an analysis of blood morphotic parameters was performed (Supplementary material).

\section{Immunoglobulins and cytokins level}

Immunoglobulins and cytokins level were measured using ELISA assay in Spectramax Plus 384 Microplate Reader (Molecular Devices) using 96-well plates coated with monoclonal antibodies against equine IgG2 (GR106527, Genorise) IgM (GR106524, Genorise), IL-6 (GR106001, Genorise), and IL-10 (GR106003, Genorise) (Genorise Scientific, Devon-Berwyn, PA, USA) (Supplementary Table S3). $100 \mu$ of plasma per well were added. Each well was washed three times with Assay Buffer after each step. $100 \mu l$ of working dilution of Detection Antibody were added and incubate 1 hour. After wash $100 \mu$ l of working dilution of Conjugate were added to each well and incubated for 20 minutes. After the wash, $100 \mu$ of Substarte Solution were added to each well, and incubated for 20 minutes. After the wash, $50 \mu$ of Stop Solution were added to each well. Duplicate wells were used for each sample. Plates were read using microplate reader set to $450 \mathrm{~nm}$. Results were calculated based on standard curve. High standard concentration of $80 \mathrm{ng} / \mathrm{ml}$ were prepared, vortexed for 15 seconds, and allowed to sit for 5 minutes. A seven-point standard curve was generated using 2-fold serial dilutions in the Assay Buffer.

\section{Statistical analysis}

Data are presented as means \pm standard error. The data were analysed using SAS 9.4 software (SAS Institute INC., USA). The Shapiro-Wilk test was considered the best test to check the normality of the distribution of a random variable. Because the data did not have normal distribution, Kruskal-Wallis test was used, with immunostimulant as effects and for interactions between group and time postimmunization on relative antibody concentration and cytokine and mRNA expressions. The relationships between all parameters (TLR4 mRNA expresion level, concetration of IL-10, IL-6 ang IgG2, IgM) were analyzed using nonparametric Spearman's rank correlation test. The value ranges from 0.0 to 0.5 , from 0.5 to 1.0 , from -0.5 to 0.0 and from -1.0 to -0.5 indicate weak positive, strong positive, weak negative and strong negative correlation, respectively. 


\section{Declarations}

\section{Ethics committee}

The authors have declared no competing Ethical Animal Research The experiment was conducted upon receiving the permission granted from the Local Ethics Committee in Kraków (no 37, 30 May 2016). Veterinary care and samples collecting were performed by vet prof. Adam Okólski. All animals used in this study were help in experimental station of University of Agriculture in Krakow.

\section{Competing interests}

The authors declare that they have no competing interests

\section{Source of Funding:}

This work was financed by the Ministry of Science and Higher Education of the Republic of Poland (funds for statutory activity, DS 3208 and SUB.2015-D201)

\section{Authors' contributions}

AM: design of the work, blood sampling and blood analysis, analysis interpretation of data; preparation of the manuscript

$Ł M$ : blood sampling and blood analysis, statistical analysis

AO: design of the work, analysis interpretation of data;

ACS: design of the work, analysis interpretation of data;

\section{References}

1. Perkins G.A.,Wagner B. The development of equine immunity: Current knowledge on immunology in the young horse Equine Vet Jour 47, 267-274 (2015)

2. Koterba A.M. Equine Clinical Neonatology. Lea \& Febiger, Philadelphia 1990.

3. Flamino M.J., Rush B.R., Davis E.G., Hennessy K., Shuman W., Wilkerson M.J. Characterization of peryferial blood and pulmonary leukocyte function in healthy foal. Vet Immunol Immunopathol 73, 267-85 (2000)

4. Lavoie J.P., Spensley M.S., Smith B.P., Mihalyi J. Absorption of bovine colostral immunoglobulins G and $M$ in newborn foals. Am $J$ Vet Res 50, 1598-1603 (1989)

5. Tallmadge R., McLaughlin K., Secor E., Ruano D., Matychak M., Julia M., Flaminio B.F. Expression of essential $B$ cell genes and immunoglobulin isotypes suggests active development and gene recombination during equine gestation. Devel. and Comp Immunology 33, 1027-1038 (2009) 
6. Nelson K.M., Schram B.R., McGregor M.W., Sheoran A.S., Olsen C.W., Lunn D.P. Local and systemic isotype-specific antibody responses to equine influenza virus infection versus conventional vaccination. Vaccine 16, 1306-13 (1998)

7. Sheoran A.S., Timoney J.F., Holmes M.A., Karzenski S.S., Crisman M.V. Immunoglobulin isotypes in sera and nasal mucosal secretions and their neonatal transfer and distribution in horses. Am J Vet Res 61, 1099-105 (2000)

8. Wilson W.D., Mihalyi J.E., Hussey S., Lunn D.P. Passive transfer of maternal immunoglobulin isotype antibodies against tetanus and influenza and theireffect on the response of foals to vaccination. Equine Vet J 33, 644-50 (2001)

9. Holznagel D.L., Hussey S., Mihalyi J.E., Wilson W.D., Lunn D.P. Onset of immunoglobulin production in foals. Equine Vet J 35,620-622 (2003)

10. Kita J., Anusz K., Zaleska M. Szczepienia koni Życie Wet. 80,625-631(2005)

11. Werner G.H., Jolles P. Immunostimulating agents: what next? A review of their present and potential medical application. Eur J Biochem. 242, 1-19 (1996)

12. Tzianabos A.O. Polysaccharide immunomodulators as therapeutic agents: structural aspects and biologic function. Clin Microbiol Rev. 13, 523-533 (2000)

13. Borchers A.T., Keen C.L., Gershwin M.E. Mushrooms, tumors, and immunity: an update. Exp Biol Med 229, 393-406 (2004)

14. Wiśniewski J., Siwicki A.K., Wiśniewska M. Wprowadzenie do ogólnej i klinicznej immunologii weterynaryjnej. Wydawnictwo UW-M, Olsztyn, 212-226 (2004) (In Polish)

15. Myśliwski A., Dzierzbicka K., Wardowska A. Immunomodulatory naturalne: muramylodipeptyd (MDP) tuftsyna modyfikowane drogą syntezy nowych pochodnych. In: Naturalne i syntetyczne modulatory odpowiedzi immunologicznej i angiogenezy, Edited by A.K. Siwicki, E. Skopińska-Różewska, Olsztyn, 27-32 (2006)

16. Higgins A.J., Snyder J.R. The equine manual second eddition Elsevier Saunders 2006

17. Jaworski, Z. Tablice Genealogiczne Koników Polskich Genealogical Tables of the Polish Primitive Horse; Stacja Badawcza Rolnictwa Ekologicznego i Hodowli Zachowawczej Zwierzat PAN: Popielno, Poland (1997) (In Polish)

18. Hoehler D. The Institute for Animal Nutrition and Metabolic Physiology; Kiel University: Kiel, Germany (1997)

19. Cohen ND. Causes of and farm management factors associated with disease and death in foals. J Am Vet Med Assoc. 204, 1644-51 (1994)

20. Vendrig JC, Coffeng LE, Fink-Gremmels J. Effects of Separate and Concomitant TLR-2 and TLR-4 Activation in Peripheral Blood Mononuclear Cells of Newborn and Adult Horses. PLoS One. doi.org/10.1371/journal.pone.0066897 (2013)

21. Tessier L, Bienzle D, Williams LB, Koch TG. Phenotypic and immunomodulatory properties of equine cord blood-derived mesenchymal stromal cells. PLoS One. doi: 10.1371/journal.pone.0122954. 
(2015)

22. Hansen S., Baptiste K.E., Fjeldborg J., Betancourt A., Horohov D.W. A comparison of pro-inflammatory cytokine mRNA expression in equine bronchoalveolar lavage (BAL) and peripheral blood. Vet Immunol Immunopathol.158, 238-43 (2014)

23. Lin X, Huang C, Shi J, Wang R, Sun X, Liu X, Zhao L, Jin M.. Investigation of Pathogenesis of H1N1 Influenza Virus and Swine Streptococcus suis Serotype 2 Co-Infection in Pigs by Microarray Analysis. PLoS One. doi: 10.1371/journal.pone.0124086 (2015)

24. Levy O., Zarember K.A., Roy R.M., Cywes C., Godowski P.J., Wessels M.R. Selective impairment of TLR-mediated innate immunity in human newborns: neonatal blood plasma reducesmonocyte TNFalpha induction by bacterial lipopeptides, lipopolysaccharide, and imiquimod, but preserves the response to R-848. J Immunol 173, 4627-34 (2004)

25. Yerkovich S.T., Wikström M.E., Suriyaarachchi D., Prescott S.L., Upham J.W., Holt P.G. Postnatal development of monocyte cytokine responses to bacterial lipopolysaccharide. Pediatr Res 62, 547$52(2007)$

26. Wagner B., Hillegas J.M., Antczak D.F. A monoclonal antibody to equine interleukin-4 Vet Immunol Immunopathol 110, 363-367 (2006)

27. Breathnach C.C., Sturgill-Wright T., Stiltner J.L., Adams A.A., Lunn D.P., Horohov D.W. Foals are interferon gamma-deficient at birth. Vet Immunol Immunopathol 112, 199-209 (2006)

28. Burton A.B., Wagner B., Erb H.N., Ainsworth D.M. Serum interleukin-6 (IL-6) and IL-10 concentrations in normal and septic neonatal foals. Vet Immunol Immunopathol. 132, 122-128 (2009)

29. Bottcher M.F., Jenmalm M.C., Garofalo R.P., Bjorksten B. Cytokines in breast milk from allergic and nonallergic mothers. Pediatr. Res. 47, 157-162 (2000)

30. Hagiwara K., Kataoka S., Yamanaka H., Kirisawa R., Iwai H. Detection of cytokines in bovine colostrum. Vet. Immunol. Immunopathol. 76, 183-190 (2000)

31. Nguyen T.V., Yuan L., Azevedo M.S.P., Jeong K., Gonzalez A., Saif L.J. Transfer of maternal cytokines to suckling piglets: in vivo and in vitro models with implications for immunomodulation of neonatal immunity. Vet. Immunol. Immunopathol. 117, 236-248 (2007)

32. Zanardo V., Golin R., Amato M., Trevisanuto D., Favaro F., Faggian D., Plebani M., Cytokines in human colostrum and neonatal jaundice. Pediatr. Res. 62, 191-194. (2007)

33. Yamanaka H., Haigiwara K., Kirisawa R., Iwai H. Transient detection of proinflammatory cytokines in sera of colostrums-fed newborn calves. J. Vet. Med. Sci. 65, 816-818 (2003)

34. Bondo T., Jensen S.K. Administration of RRR-a-tocopherol to pregnant mares stimulates maternal IgG and IgM production in colostrum and enhances vitamin $E$ and IgM status in foals. J Anim Physiol Anim Nutr (Berl) 95, 214-22 (2011)

35. Flaminio M.J., Rush B.R., Shuman W. Peripheral blood lymphocyte subpopulations and immunoglobulin concentrations in healthy foals and foals with Rhodococcus equi pneumonia. J Vet Intern Med. 13, 206-12 (1999) 
36. Flamino M.J., Rush B.R., Davis E.G., Hennessy K., Shuman W., Wilkerson M.J. Characterization of peryferial blood and pulmonary leukocyte function in healthy foal. Vet Immunol Immunopathol 73, 267-85 (2000)

37. Ryan C., Giguère S. Equine neonates have attenuated humoral and cell-mediated immune responses to a killed adjuvanted vaccine compared to adult horses. Clin Vaccine Immunol. 17, 1896-902 (2010)

38. Jacks S., Giguere P.C., Crawford W., Castleman L.Experimental infection of neonatal foals with Rhodococcus equi triggers adult-like gamma interferon induction. Clin. Vaccine Immunol. 14, 669677 (2007)

39. Felippe M.B. Equine Clinical Immunology, Wiley-Blackwell (2016)

40. Lewis M.J, Wagner B., Woof J.M. The different effector function capabilities of the seven equine IgG subclasses have implications for vaccine strategies. Mol Immunol. 45, 818-27 (2008)

\section{Figures}

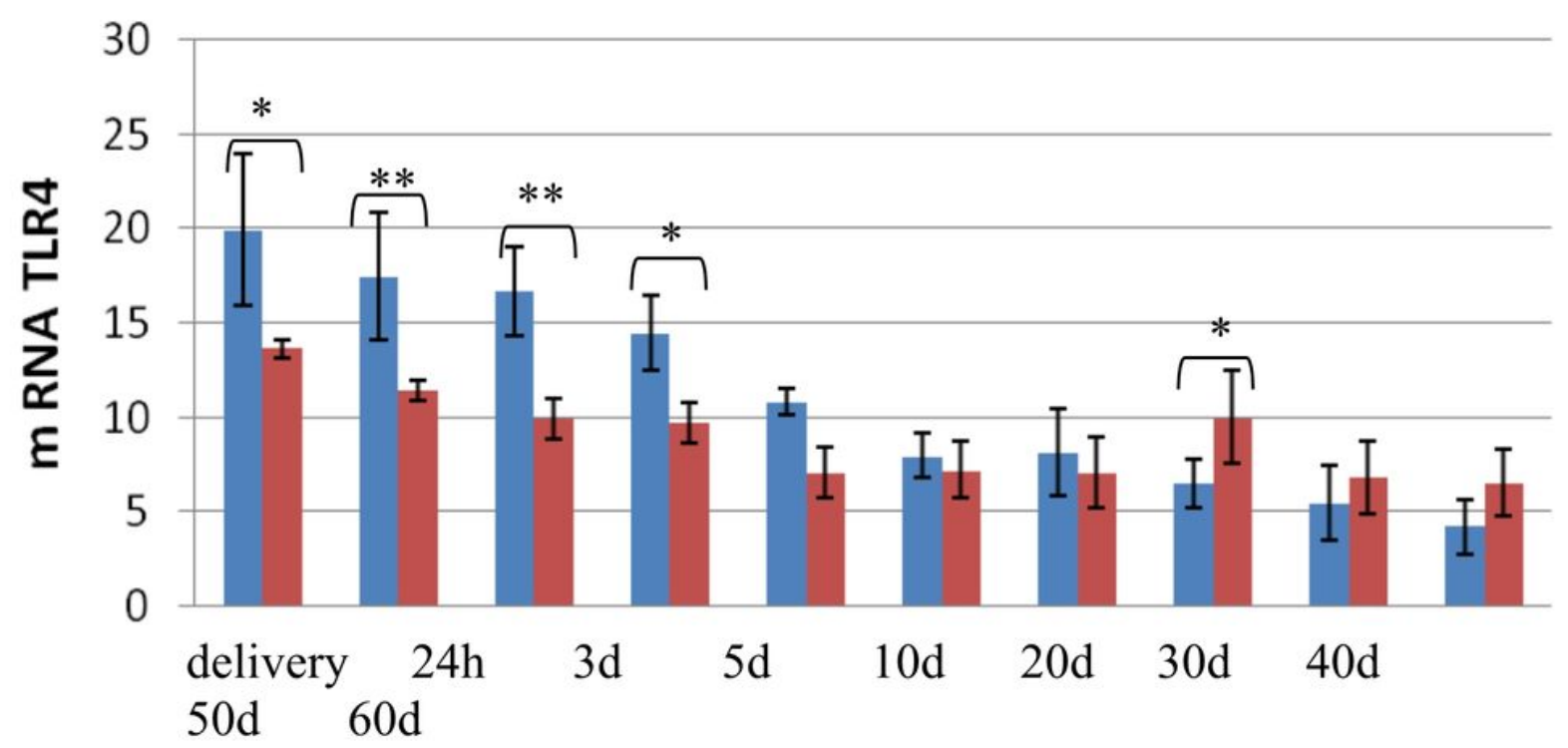

Group E Group C

\section{Figure 1}

Trends in changes of TLR4 gene expression after immunization

${ }^{1}$ delivery - sample collected at delivery; $24 \mathrm{~h}$ - sample collected $24 \mathrm{~h}$ after delivery; $3 \mathrm{~d}$-sample collected $3^{\text {rd }}$ days after delivery; $5 \mathrm{~d}$ - sample collected $5^{\text {th }}$ days after delivery; $10 \mathrm{~g}$ - sample collected $10^{\text {th }}$ days after delivery; $20 \mathrm{~d}$ - sample collected $20^{\text {th }}$ days after delivery; $30 \mathrm{~d}$ - sample collected $30^{\text {th }}$ days after delivery; $40 \mathrm{~d}$ - sample collected $40^{\text {th }}$ days after delivery; $50 \mathrm{~d}$ - sample collected $50^{\text {th }}$ days after delivery; $60 \mathrm{~d}$ sample collected $60^{\text {th }}$ days after delivery

2 means are reported with their standard errors 
Group C - control group; Group E - experimental group stimulated multi-component bacterial immunomodulator (injection in 35th and $40^{\text {th }}$ days after delivery)

* means in row/line for receptor show significant differences $(p<0,05)$

** means in row/line for receptor show highly significant statistical differences $(p<0,01)$

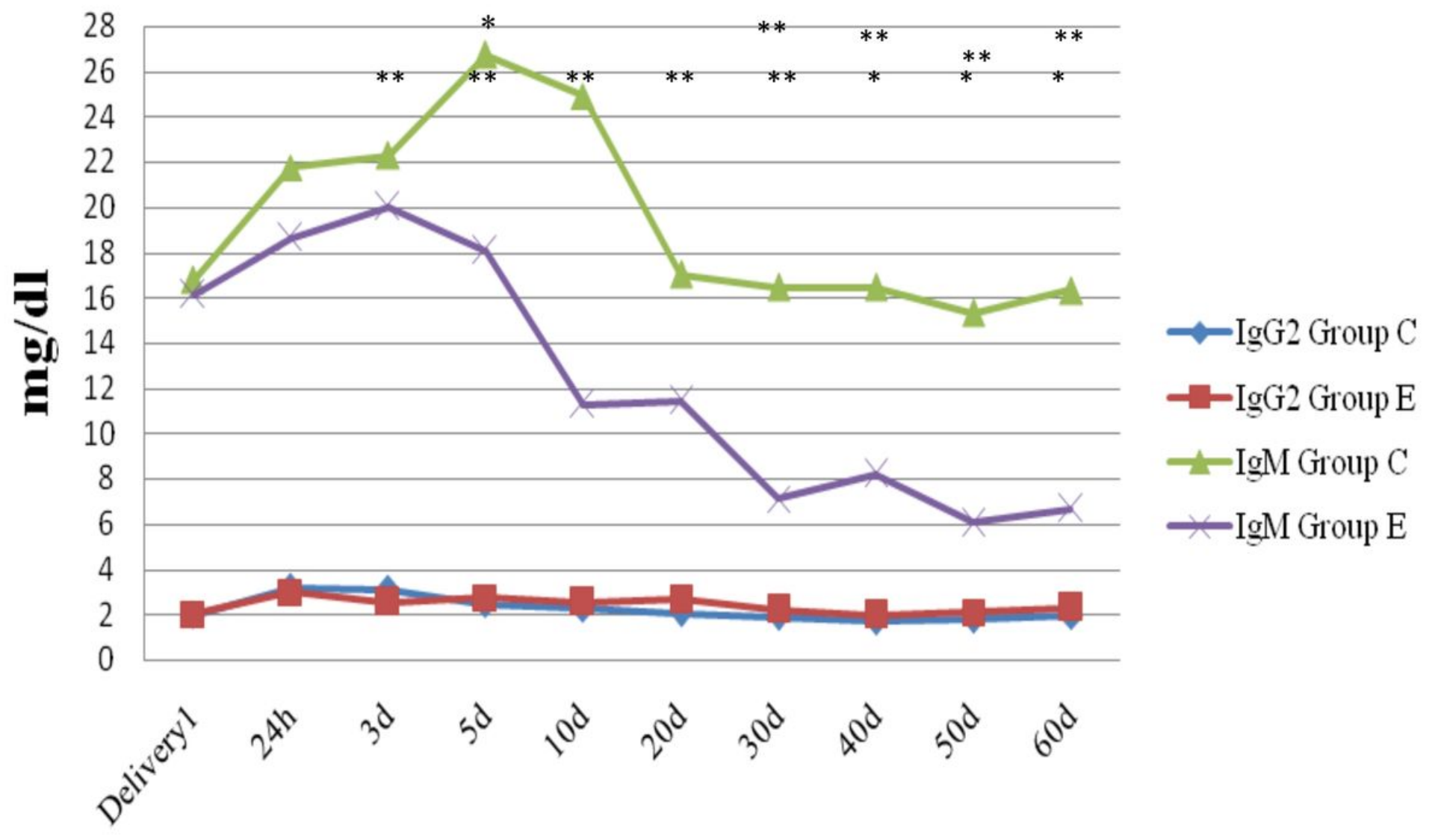

\section{Figure 2}

Influence of immunization on $\lg M$ and $\lg G 2$ concentration

${ }^{1}$ delivery - sample collected at delivery; $24 \mathrm{~h}$ - sample collected $24 \mathrm{~h}$ after delivery; $3 \mathrm{~d}$-sample collected $3^{\text {rd }}$ days after delivery; $5 \mathrm{~d}$ - sample collected $5^{\text {th }}$ days after delivery; $10 \mathrm{~g}$ - sample collected $10^{\text {th }}$ days after delivery; $20 \mathrm{~d}$ - sample collected $20^{\text {th }}$ days after delivery; $30 \mathrm{~d}$ - sample collected $30^{\text {th }}$ days after delivery; $40 \mathrm{~d}$ - sample collected $40^{\text {th }}$ days after delivery; $50 \mathrm{~d}$ - sample collected $50^{\text {th }}$ days after delivery; $60 \mathrm{~d}$ sample collected $60^{\text {th }}$ days after delivery

2 means are reported with their standard errors

Group C - control group; Group E - experimental group stimulated multi-component bacterial immunomodulator (injection in 35 th and $40^{\text {th }}$ days after delivery)

* means in row/line for receptor show significant differences $(p<0,05)$ 
** means in row/line for receptor show highly significant statistical differences $(p<0,01)$

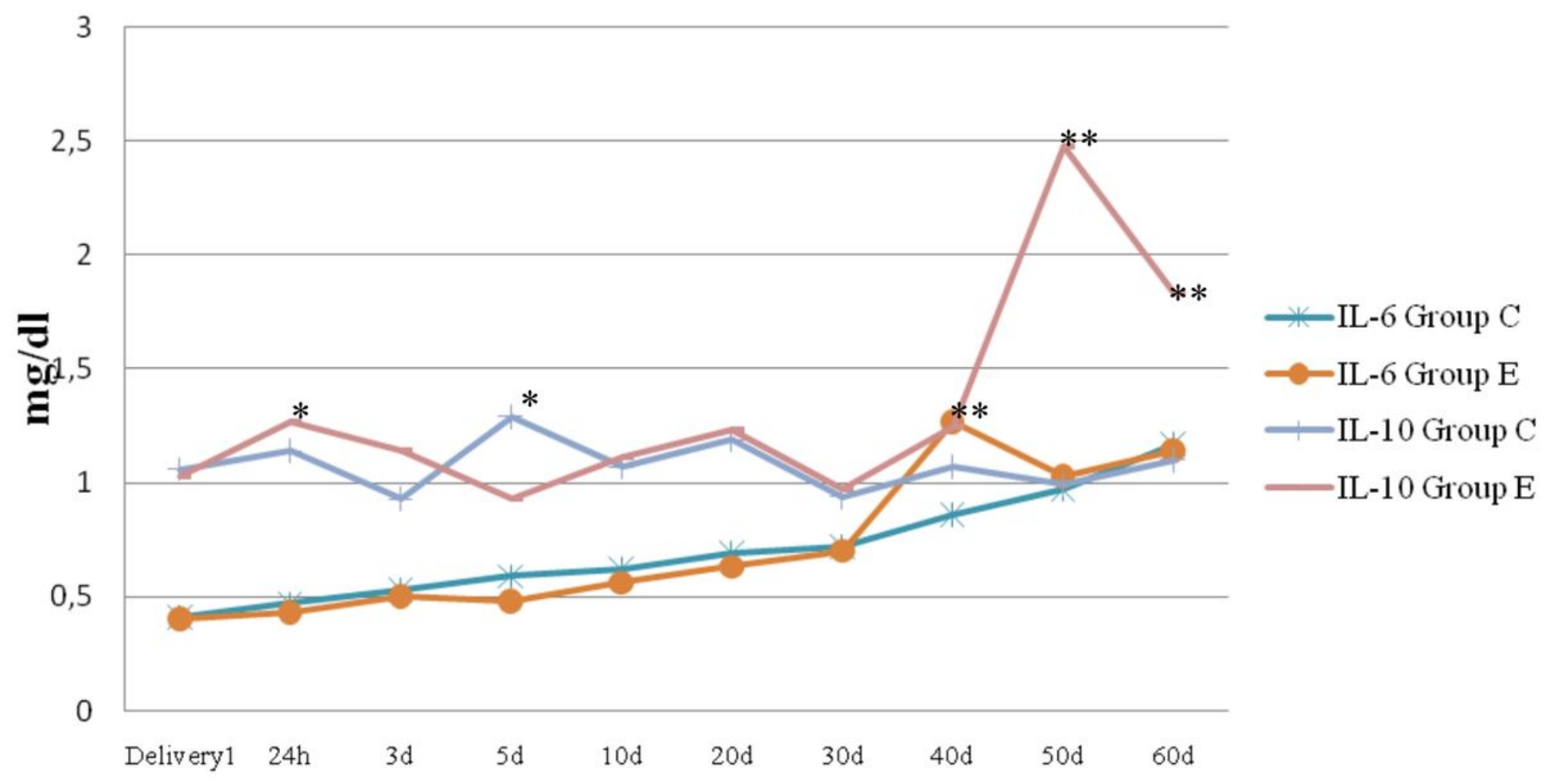

Figure 3

Influence of immunization on IL-6 and IL-10 concentration

${ }^{1}$ delivery - sample collected at delivery; $24 \mathrm{~h}$ - sample collected $24 \mathrm{~h}$ after delivery; $3 \mathrm{~d}$-sample collected $3^{\text {rd }}$ days after delivery; $5 \mathrm{~d}$ - sample collected $5^{\text {th }}$ days after delivery; $10 \mathrm{~g}$ - sample collected $10^{\text {th }}$ days after delivery; $20 \mathrm{~d}$ - sample collected $20^{\text {th }}$ days after delivery; $30 \mathrm{~d}$ - sample collected $30^{\text {th }}$ days after delivery; $40 \mathrm{~d}$ - sample collected $40^{\text {th }}$ days after delivery; $50 \mathrm{~d}$ - sample collected $50^{\text {th }}$ days after delivery; $60 \mathrm{~d}$ sample collected $60^{\text {th }}$ days after delivery

2 means are reported with their standard errors

Group C - control group; Group E - experimental group stimulated multi-component bacterial immunomodulator (injection in 35 th and $40^{\text {th }}$ days after delivery)

* means in row/line for receptor show significant differences $(p<0,05)$

** means in row/line for receptor show highly significant statistical differences $(p<0,01)$

\section{Supplementary Files}

This is a list of supplementary files associated with this preprint. Click to download. 
- SuplementarymaterialRS.doc 